\title{
Balkanologie
}

Balkanologie Revue d'études pluridisciplinaires

Vol. IV, $n^{\circ} 1 \mid 2000$

Volume IV Numéro 1

\section{Turbaši and Rokeri as Windows into Serbia's Social Divide}

Eric D. Gordy

\section{(2) OpenEdition}

1 Journals

Édition électronique

URL : http://journals.openedition.org/balkanologie/774

DOI : $10.4000 /$ balkanologie. 774

ISSN : 1965-0582

Éditeur

Association française d'études sur les Balkans (Afebalk)

Édition imprimée

Date de publication : 1 septembre 2000

ISSN : 1279-7952

\section{Référence électronique}

Eric D. Gordy, «Turbaši and Rokeri as Windows into Serbia's Social Divide», Balkanologie [En ligne], Vol. IV, $n^{\circ} 1$ | 2000, mis en ligne le 29 juillet 2010, consulté le 17 décembre 2020. URL : http://

journals.openedition.org/balkanologie/774; DOI : https://doi.org/10.4000/balkanologie.774

Ce document a été généré automatiquement le 17 décembre 2020.

(c) Tous droits réservés 


\title{
Turbaši and Rokeri as Windows into Serbia's Social Divide
}

\author{
Eric D. Gordy
}

1 "Culture is ordinary " argues Raymond Williams ${ }^{1}$, and so certainly is politics. Both, however, face unique - and, perhaps extraordinary - conditions of articulation, signification and association under conditions of authoritarian political rule. The most frequently expressed concerns about culture in liberal states have to do with capacities of information or control, with subcultural and resistant power, and with representation and justification of order. All of these concerns are in a sense reflections of larger political concerns, in which cultural manifestations in a way "stand for" issues which are, elsewhere in the cultural apparatus, issues of political deliberation and debate in a relatively accessible public sphere. Outside of liberal states, the deliberative space of the public sphere may be far more restricted : participation in public life can be more limited, discussion of contemporary issues may be excluded from generally accessible communication media, and sensitive questions may be systematically not recognised as public issues.

2 Under such conditions, issues which are excluded from the public sphere do not, naturally cease either to exist or to mater. The lack of access to formal expression through the "ordinary" channels of recognized political institutions or news media assures their disappearance only from those particular areas of public life. Political battles, which are exiled from politics, are then fought on another terrain. In this discussion, I propose to demonstrate that while the rural-urban cultural conflict in contemporary Serbian society, which is expressed by the current regime's nationalist policies and ambitions and by the urban and cosmopolitan opposition to the regime, is only weakly articulated in "official" public discourse, this conflict provides much of the force and content of the passionate disputes in the life of popular culture, especially in conflicts over musical taste. Recognized political channels are closed to the deliberation of claims and grievances on the part of peasants, "peasant urbanites" ${ }^{2}$ and urban cosmopolitans, but the debate is nonetheless carried out in the field of popular music. While musical channels do not afford all of the techniques and remedies 
associated with the public sphere, they do possess considerable capacity for the expressive and emotional elaboration of positions in this conflict, and the struggle over cultural space offered a parallel to the political debate which did not and could not take place.

It should be apparent here that the rural-urban divide is not a strictly geographical distinction, but represents one of the ways in which people in Serbia articulate and understand the distinction between nationalist and cosmopolitan orientations. The two musical publics discussed here are both located in Belgrade, indisputably a city. Within that city, cosmopolitan rokeri and "peasant urbanite" turbeši are distinguished by where they look for cultural referents. Consequently this discussion deals with two displacements : the articulation of political issues through conflicts in popular culture, and the articulation of conflicts over national and cosmopolitan outlooks by reference to a mostly imagined geographical difference.

\section{Cultural antecedents of nationalist power}

4 What are the factors which account for the rise of nationalist politics in Serbia and, consequently, the wars of succession in the former Yugoslavia? I have analyzed the details of this process in greater detail elsewhere ${ }^{3}$, but for now I will simply outline the principal factors which explain the rise of the SPS regime in Serbia and identify the sources of its continuing support. These are :

5 - on the intellectual level, the relative openness of the Communist regime made exchange and travel relatively easy. This encouraged the most successful intellectuals to seek European or international careers, or to pursue their activity domestically without having to take extensive account of the needs or desires of domestic institutions. Domestic institutions, then, which existed only at the level of republics, maintained a largely deserved reputation as the intellectual homes of the mediocre. To the extent that they succeeded in establishing intellectual authority for themselves, it was by endeavoring to articulate the cultural and political frustrations of local populations. The emergence of nationalist politics in Serbia in the late 1980's is associated with the developing alliance between peasant and "peasant urbanite" resentment and the voice of these sentiments among members of local academic institutions, especially the Serbian Academy of Sciences and Arts (SANU) and the Union of Writers of Serbia (UKS) ${ }^{4}$;

6 - on the political level, there was a negative response to the Communist policy of favoring urban and industrial development over the agricultural sector. As an ideological matter, these priorities reflected the concern of Marxism-Leninism with the development of an urban proletariat, while as a political matter they offered a means to develop local clienteles through the distribution of development largesse. But as economic policy, these priorities reflected the capacities of the former Yugoslavia rather poorly, and were implemented with little attention paid to maximizing efficiency or minimizing corruption. When the policy exploded in the face of local disputes over misallocation of resources and an international debt crisis, the moment came for representatives of the agricultural sector to demonstrate their resentment against the favoring of cities, urban development and urban culture by the Communist regime $^{5}$; 
7 - on the social level, the growth of urban populations, urban culture and the urban middle class widened the cultural division between young, educated urban residents on the one hand, and older, less educated rural and "peasant-urbanite" groups on the other. Especially important here were distinctions regarding cultural horizons and cultural orientations. While the young urbanites developed cosmopolitan cultural orientations, and often migrated in the pursuit of these orientations, peasants and "peasant urbanites" retained cultural connections to villages, regions and "nations". The urban centers of Serbia, Belgrade especially, came to be viewed among nationalists as "not really Serbian", and in some articulations as inherently traitorous ${ }^{6}$.

8 The deep and unresolved cultural divisions and tensions which developed over the last half-century in Serbia are not unique in history; a similar pattern characteristically follows processes of urbanization and modernization and can indeed be said to lie behind such foundational sociological concepts as Durkheim's construction of "anomie" or Weber's "disenchantment of the wold". Arno Mayer connects this "simultaneity of the unsimultaneous" to the rise of Nazism and authoritarian movements 8 . What made their development in Serbia and other parts of the former Yugoslavia interesting was that they occurred in a political atmosphere which was structurally authoritarian while it was culturally relatively open. Neither the Communist regime nor the nationalist-authoritarian regime which succeeded it afforded space in the public sphere for deliberation over the concrete conflicts between the developing cosmopolitan culture of the cities and the residual rural and "peasant urbanite" cultures which existed alongside it.

But tensions, which were not openly articulated as issues in the public sphere, did not disappear or fall silent. Rather they migrated to private spheres of pleasure, taste and enjoyment, where they were used to signify larger cultural, and later political orientations. News accounts, the distribution of protests and election returns can demonstrate to us the concentration of support for Serbia's nationalist-authoritarian regime among older, rural and less educated portions of the population - and the concentration of opposition to it among the young, urban and more educated. The conflict between the peasant and "peasant-urbanite" culture's favored neo-folk music and the rokenrol of the urban centers, as it was played out during the years (1990-1996) of nationalist mobilization and war, offers a way for us to understand what this deep social and political division meant to the people who experienced it in everyday life.

In the first half of this decade, the city of Belgrade saw the defeat of an urban-oriented culture and the rise of a nostalgic urban.-peasant power which elaborated its claims through the rhetoric of nationalism. Opponents of nostalgia-in-power articulated their distaste, at least in part, by means of their musical caste from the centers of power came a critique directed in no small measure toward that taste. Therefore much of the open discourse about nationalism took place on the field of popular music - with concerns about openness and authenticity, and discomfort with these categories, apparent on both sides

11 The dual peasant and urban character of Belgrade's culture, long a source of social division and political conflict, came to the fore. As the nationalist-authoritarian regime established itself and attempted to promote nationalist mobilization, they found one group particularly disinclined to cooperate : the young urban population. The members of this group and the rock ' $n$ ' roll culture which defined them came under attack. Instead, heavy promotion was offered to two variations of nostalgia in music : neofolk, 
long promoted in state media and popular in the provinces and in the peripheries of cities, and turbo-folk, an intensified effort to update and speed up the neo-folk genre. With the diminution of cultural space available to the rock ' $n$ ' roll culture, its members, already removed from influence, were made to feel more intensively isolated in an environment which was hostile to them culturally as well as politically. As the rock ' $n$ ' roll culture moved from the center to the margins, however, it became more uncompromising and more conscious of itself as a lifeline to Belgrade's cosmopolitans. Musical taste became an important signifier, not only of the distinction between urban and peasant culture, but also of orientation toward the regime, the war, and the social environment. The expression of musical taste became more vehement and passionate, especially among Belgrade's rokeri who saw themselves as the last line of defense of urban culture.

\section{Conquest of commercial cultural space : From Neo-folk to Turbo- folk}

As Belgrade's rock ' $n$ ' roll culture came under attack, the regime was not so certain of the attractiveness of its program that it believed that culture is entertainment and diversion were not required. Some form of popular entertainment had to be promoted, and several factors offered neo-folk as the most opportune candidate. First, except in the cities, neo-folk was already widely publicized and widely popular, so a basis had been laid and no great investment was required to promote the music. Second, neo-folk musicians had been, since at least the early 1960's, eagerly bringing electrical and amplified sounds, as well as rhythms and styles from western popular music, into their own repertoire'. Third, while rock ' $n$ ' roll had been generally identified in Yugoslavia as a music of rebellion, individualism, and resistant postures, folk forms had not had such an image since the waning days of the Ottoman Empire. Ivan Čolović describes the principal forum for neo-folk music on local radio dedication programs :

They follow and confirm the exchange of signs of care and love occasioned by important events in the lives of individuals and families, such as birthdays, entry into school, enrollment in the university, graduation, entry into the army, return from the army, a fianceement, marriage, receiving employment, the birth of a child, setting off to work in other countries, return from other countries, moving into a new house, receiving electricity, buying a car, receiving a drivers' licence, retirement, returning from the hospital, etc. There are happy occasions and successes which merit congratulations and good wishes and which should be made general knowledge and, and so the sending of appropriate messages by the radio, with the dedication of songs, forms a part of the system of neofolkloric symbolic communication. ${ }^{10}$

So while rock ' $n$ ' roll sought to express an orientation outside of the general social order, neo-folk had a place right within it, as a part of the system of mainstream communication, especially in the small towns and villages ${ }^{11}$.

Most importantly, however, neo-folk artists willingly offered musical forms for use as nationalist agitprop ${ }^{12}$. The most recognizable nationalist "folk" songs, "Marš na Drinu" (March to the Drina [River]) and "Tamo daleko" (Over There) in Serbia date from the First World War, and in the Second World War all of the fighting groups composed songs in the folk style to promote their armies and causes. Consistent with its mainstream cultural orientation, the neo-folk genre produced many a patriotic song in the Communist era, «sung in honor of Tito, the Party, and Yugoslavia $»^{13}$. In this 
regard, some historical basis exists for associating neo-folk music with the cultural glorification of groups in power. The association applies particularly in regard to national movements ${ }^{14}$,as Čolović observes : «that folklore and politics, at least when the question is about [Serbia], are connected with one another from the very beginning, is clear from Vuk Karadžić's revelation (more precisely : representation) of folklore as the framework of the life of the nation $»^{15}$.

Slobodan Milošević tied his rise as a political figure to cultural projects of "national revival" as well as to political projects of emphasizing national grievances, as in Kosovo. Popular response was expressed both in slogans composed in the folkloric key and in neo-folk songs dedicated to presenting the new leader in the light of a national hero. Čolović cites many of these songs, both from his observations of political meetings and from agitprop cassettes, among which is the song "Čovek dvadesetog veka » (Twentieth Century Man) :

Mila braćo, došlo novo doba / Dear brothers, the new era has come

Rodio se Milošević Sloba / Sloba Milošević is born ${ }^{16}$.

In this regard too,the ground had been laid for neo-folk to take the role of the regime's favorite genre, legitimating the projects of the regime by associating them implicitly with other national traditions.

The cultural ante was raised as war neared and then finally arrived, folk performers took the lead in producing agitprop cassettes of "patriotic" and militaristic songs on all sides of new and future borders. The cheap production and poor quality of performance on most of these cassettes indicate that they were produced hurriedly, and with more of an eye toward agitprop among specific pre-selected groups than toward any potential commercial market ${ }^{17}$. One indication of how hurriedly composed the selections were: Serbian and Croatian nationalist folk performers often used the same songs, many of them borrowed not only from the World War II-era songs of the Četnici and Ustaše but also from the old Communist catalog of pro-regime folk songs, with only a few alterations in the lyrics distinguishing the versions on either side of the border from one another ${ }^{18}$.Together with the music came cultural claims regarding the "naturalness" of folk forms both for the purpose to which they were put and for the people for whom they were intended.

A brief period of promotion of agitprop neo-folk coincided with the period of nationalist mobilization. In Belgrade, an all-agitprop radio station, Radio Ponos (Radio Pride), offered a program of "only Serbian folk songs, of those only the "really Serbian" ones $»^{19}$. The wave of political war-folk lasted briefly, however, as the regime turned from mobilizing for and promoting the (incipient and "defensive") war to attempting to silence and marginalise the (ongoing and criminally embarrassing) war as it developed. Radio Ponos was shut down suddenly in 1994, when the regime made its political move away from public support for its client para-states in Croatia and Bosnia-Hercegovina. The nationalist folk movement survived «as a phantom radio movement which occasionally organizes benefit concerts (with singers from the second and third folk-leagues) $»^{20}$.

Neo-folk survived the cutting off of its agitprop branch, however, and developed in a new direction. The tremendous publicity which folk celebrities received in state media as the rock ' $n$ ' roll market vanished, and the perceived need for some material to fill the void left by the evaporation of the rock ' $n$ ' roll mainstream created an opportunity for the neo-folk market to speed up and exponentially deepen a transformation which 
had been going on for a long time. From the first moment that neo-folk composers and writers began addressing contemporary themes ${ }^{21}$, and from the first moment that neofolk performers switched from peasant garb and formal suits to fashionable clothing, neo-folk had been on a long trek, to extend an analogy heard many times in the course of research and noted frequently by scholarly observers ${ }^{22}$, from Nashville to Broadway. Political war-folk was a brief and regime-pleasing step backward on that journey, but when that ended the adaptation of commercial forms, values, and techniques by the most successful neo-folk performers became complete.

The new direction combined neo-folk, with varying degrees of success,with images of the consumer high life, synthesized and amplified sounds, beats borrowed from western commercial dance music,and styles of presentation borrowed from MTV. Its promoters called the music "turbo-folk". Turbo-folk became the house style of new and expensive venues like the Folkoteka in New Belgrade and new television stations like TV Pink and TV Palma, and it became the soundtrack music of the new urban subculture of dizelaši, young toughs so called in recognition of their favorite clothing manufacturer (Diesel), and also because many of them seemed to be employed in various types of illegal activity epitomized by the street trade in smuggled motor fuels. Though the music continued to be identified by its performers, promoters, and fans as "folk", folk elements fell quickly out of the mix, to be replaced by the accoutrements of MTV dance culture as understood by Serbia's peasants and peasant urbanites.

While turbo-folk's radical extension of the influence of western commercial pop styles did represent a continuation of a process of change that had been occurring in the neofolk genre for at least two decades, it can hardly be thought of as an "organic" development. Most of the products of the genre can be traced to a few specific sources : the dance school operated by Hamid Đogani of the band Đogani fantastico, the songwriting and composition team of Marina Tucaković and her husband Aleksandar Radulović-Futa, the composers and arrangers Zlatko Timotić-Zlaja and Zoran StarčevićStari, and the record label ZAM (Zabava miliona - Entertainment of the Millions) owned by former folk-pop sensation Fahreta Jahić-Lepa Brena and distributed by PGP-RTS.

An archetypal turbo-folk video is perhaps Ivan Gavrilović's song 200 na sat (200 [kilometers] an Hour), a paean to the joys of fast driving filmed in what appears to be a showroom for Renault automobiles. The song begins with the chant "Folk! Folk! Techno-folk !", and then Ivan sings the lyrics while behind him dance four members of the Funky House Band in colorful mechanics' jumpsuits. In its musical and lyrical, as well as visual, aspects the song is not distinguishable from any of a number of instant synthesized dance hits. That is until the song reaches a bridge, which consists of a few seconds of folk-style accordion playing - just the suggestion of reference to a folk tradition. The trend would continue as turbo-folk developed, with more folk elements falling out of the mix. Finally, only two musical elements identified with "folk" would remain in the music: the sound of accordions (often only suggested by a similar sound from a synthesizer), and the tremor in the voice characteristic of some types of traditional duophonic singing, generally described by the derogatory term "zavijanje"(bowling). Even these would remain in the music inconsistently, with the accordion sound absent or confined to a single phrase, or with the "zavijanje" appearing only, for example, at the end of a line in the chorus ${ }^{23}$.

23 Another aspect of the turbo-folk ascendancy appears in the video spot mentioned, and came to largely characterize its domination. As opposed to the briefly publicized wave 
of nationalist agitprop, turbo-folk was rarely engaged with national or any other kinds of political questions in a self-conscious way. Lyrically, the dominant orientation of turbo-folk, as with most popular commercial musical forms, was toward songs about relationships, romance, and love. Visually, there was a strong orientation to images of glamour, luxury, and the "good life" as imagined by the peasant urbanites - a world populated by young women in miniskirts who drive luxury automobiles, live in fantastically spacious homes and spend their time in fashionable hotel bars. In contrast to the older neo-folk which had as a repeated theme the sadness of the migrant to the city and the image of the rustic idyll of the past ${ }^{24}$, turbo-folk presented the good life as a feature of the Serbian present - something which, given the conditions of general poverty and international isolation, was available only to a small group generally considered to constitute a new criminal elite. Occasionally these images found their way into turbo-folk lyrics :

Coca-Cola, Marlboro, Suzuki / Coca-Cola, Marlboro, Suzuki

Diskoteke, gitare, buzuki / Discotheques, guitars, and bouzouki

To je život, to nije reklama / That's life, that's not an ad

Nikom nije lepše nego nama / Nobody has it better than us.

24 And :

Lepo mi je sve / Everything is fine for me

Samo tako neka ostane / Just let it stay that way.

25 Two ideological purposes, it seems, are filled by this style of presentation. In the first place, the representation of glamour and luxury offered strong escapist diversion from the actual situation in which most of the members of the audience lived, while complementing the official lines regarding international sanctions against Serbia and regarding the fighting going on in Croatia and Bosnia-Herzegovina - that these faraway events cannot affect people at home. Second, by presenting the lifestyle of the new criminal elite in a glamorous and romantic light, the ascendancy of this group was made to appear normal and acceptable.

The preceding discussion points out several distinctions between turbo-folk and earlier neo-folk, many of them musical. Given the paucity of folkloric elements in the music, then, the question ought to be asked: what is "folk" about "turbo-folk" ? An answer grounded in musicological distinctions cannot be given ${ }^{25}$. Sociological elements - the fact that the music is marketed as folk, and that its principal audience shares demographic characteristics with earlier neo-folk audiences - define it as folk. In this regard the category of "folk" can be regarded not as a descriptive aesthetic category, but as a construction derived from other basic social oppositions : the urban against the rural and semi-urban publics, and as a parallel, rock ' $n$ ' roll against folk. In the war period, the interests of the party in power in Serbia found their greatest resonance among the social groups which broadly constituted the neo-folk audience, and the least among those which broadly constituted the rock ' $n$ ' roll audience. In this sense important political and social divisions came to be expressed in differential access to media and publicity, which were widely interpreted as representing the cultural orientation of the regime.

As turbo-folk consolidated its dominance over the musical soundscape of cities as well, employing more elaborate and expensive production and promotion techniques, several of its products could be viewed as taking its position of official favor as its theme. One of the genre's major stars, Svetlana Veličković-Ceca, produced videos promoting her songs which were indistinguishable in style and in production values 
from the MTV videos turbaši took as their gold standard, drawing attention not only to the star and the music, but also to the high production budget she had at her disposal, a rarity given both cultural and economic conditions in Serbia. Her ostentatious marriage to state-sponsored paramilitarist and organized-crime king Željko Ražnatović-Arkan in February 1995 was a public spectacle of the first order. The ceremonies and celebrations surrounding the event were televised live, and marketed as a videotape by the state-owned PGP-RTS. The wedding merited both a full-page photo on the front of the regime-run newspaper Večernje novosti and a two-page photo layout in the center of the paper. To many local observers, the huge publicity given the event symbolized the relationship between turbo-folk, the state-controlled media, and the new criminal elite, much as the marriage itself seemed to represent the consummation of this complex relationship.

Another major statement of the arrival of a new urban-peasant class to power came in the song by Dragan Kojić-Keba, "U crno obojeno» (Colored Black) - his translation / cover / transformation of the Rolling Stones' iconic "Paint It Black". The stylistic differences between Keba and Jagger and Richard, however, could not be clearer. Zoran Starčević-Stari's guitar hook was not Keith Richard's famous wiggly sound but an aggressive, rhythmic reduction of it. And while Mick Jagger's original lyrics to the song stand as a classic representation of the dark and desperate worldview which the Stones refined in the late 1960's and early 1970's, Keba set his own song of the pathos of spurned love to Jagger's meter. Compare Jagger's desperate :

I see the girls walk by

dressed in their summer clothes.

I have to hold my head

Until the darkness goes.

with Keba's rendition of the verse :

Bog mi je dao sve / God gave me everything

dao i uzeo. / Gave and took away

Kao tebe nikoga / I've never loved anybody

nisam voleo. / as much as you.

Keba claimed that the inspiration for the cover came from a desire to show respect for the music which he and Stari enjoyed in their youth, in the long-ago days when rock ' $n$ ' roll was contemporary music :

To make myself clear, the Stones' songs have been sung in Romanian, German, Italian, so why shouldn't a Serb like me be able to sing them ? Zoran Starčević and I got the idea of covering that song because we listened to that kind of music as kids. That song has a lot of elements of our folklore although maybe that might sound astonishing. Its harmonic resolutions are very close to ours. So, you could say that the Stones ripped us off. Why not? (...) Nobody has said that I sing the song badly, but a lot of people wonder what right I have to sing it. It simply bothers them that a folkie (narodnjak) did the cover ${ }^{26}$.

31 For many Belgraders who heard the song, though, it was an historic document epitomizing the new dominance of turbo-folk. Turbo-folk owned the television, the large concert venues, the kafane and the radio. And now, apparently, turbo-folk owned the back catalog of the Rolling Stones as well, laying claim to the rock 'n roll culture's holiest of holies ${ }^{27}$. 


\section{Rokeri from center to margin} regarded as being composed of "peasants" (seljaci) and "primitives" (primitivci). As Srđan Gojković-Gile, leader of the punk-pop group Električni orgazam, recalls his high school days, " in my time, in my high school class there were maybe two unfortunate types who listened to folk, and they were completely written off (prokazani) ${ }^{28}$. Especially in the 1980s, Belgrade youth generated a rock 'n' roll culture which, at least in the minds of local fans, was on a par with the pop scenes of Western Europe. In 1981 the British music magazine New Musical Express listed the Belgrade art students' club Akademija as one of the finest music clubs in Europe. It also rated Belgrade's punk-pop group Električni orgazam as one of the finest bands in Europe. As late as 1995, Ljubljana's legendary Radio Student promoted its "You Rock it" program with, " certain critics put ex-Yugoslav rock ' $n$ ' roll bands in third place - after American and British bands ${ }^{29}$.

Električni orgazam's appearance on the scene illustrates the quick and definitive conquest of cultural space by Belgrade's rock ' $n$ ' roll youth. The band's first popular success was the song "Zlatni papagaj" (the golden parrot), which remains their best known song. Dedicated to the first fancy privately-owned cafe in Belgrade, the song ridicules its customers and attitude ${ }^{30}$ in a chorus that is universally known among young people in Belgrade :

$$
\begin{aligned}
& \text { zlatni papagaj - tata plati sve račune / The golden } \\
& \text { parrot - Daddy pays all the bills } \\
& \text { zlatni papagaj - jer mi smo snobovi / The golden } \\
& \text { parrot - because we're snobs }
\end{aligned}
$$

In the video promoting the song, Gile and the band members shout the lyrics and frolic in and around the cafe Zlatni papagaj, happily advertising both the song and the cafe that is the object of the song's ridicule. More than demonstrating that the owners of the cafe are good sports, the video announced the arrival of a new urban cultural order, with punk rock right in the center. Its place was in the center of the city, in the same place as the fancy cafes, as the cultural form which defines what life in the city is about. "Yugo-rock's" place was not only in the city of Belgrade. Zagreb, Ljubljana, Sarajevo, and other urban centers all developed strong local musical scenes, in intensive contact with one another. As a rule, popular bands made their records, and often built their publics, more successfully in other republics than at home. This was true for Električni orgazam, a band which would repeatedly take opportunities to demonstrate publicly its antiwar orientation in later years, who recorded principally for the Zagreb based Jugoton (later Croatia Records) ${ }^{31}$. It was, no less true for Riblja Čorba, whose leader Bora Đorđević would later become a vocal supporter of Arkan, and who recorded principally for RTV-Ljubljana ${ }^{32}$.

But the rock ' $n$ ' roll culture did remain an urban culture, while neo-folk continued to dominate the taste of the provinces. Before provincial culture came to political dominance with the rise of nationalism, taste was already a marker both of identity and of orientation toward the regime. In this regard the individualism and pleasurecenteredness of the rock aesthetic played a defining role. Noise-rock pioneer Dušan Kostić-Koja, leader of the band Disciplina kičme (Discipline of the spine), staked out a cultural position opposed to the conformity of mainstream popular culture, singing :

Mnogo ljudi ne zna / Many people don't know how

Balkanologie, Vol. IV, $n^{\circ} 1$ | 2000 
Mnogo ljudi ne sme / Many people do not dare to

Doživeti tu radost / Experience the pleasure

Moje lepe pesme / of my beautiful song roll market. It was impossible for regime supporters not to notice that their support was weakest by far among the young urban population - a fact made clear to them repeatedly in the political protests of 1991 and the student protests of 1992, and in the massive refusal of calls to military service ${ }^{34}$.It was also easy enough to observe that the young urbanites' refusal to follow along on the path of war was encouraged by the rock 'n roll culture that characterized them. Particularly active in this regard was the unlicensed "youth radio" station, B-92, which combined its rock ' $n$ ' roll-centered programming with the only independent radio news program in Belgrade, as well as with a number of performance-like public "actions" against the war and the conditions associated with it.

41 So whether or not the regime had any reason or desire to act against rock ' $n$ roll it had every reason to want to discourage the attitudes and activity of the rock ' $n$ roll public. Regime ideologists were never unclear as to their opinion of the culture of Serbia's urban youth. Dobrica Ćosić, the novelist to whom the inspiration for Milošević's national program is generally attributed ${ }^{35}$, groups together among the spiritual enemies of the nation a variety of exponents of modernity : " [Yugoslavism in its "evil incarnation" is] an expression of a political parvenu mentality; of the snobbery of a pan of the rock-and-roll generation; of the cosmopolitanism of liberal intellectuals ; of a legitimate and "progressivist" and "democratic" mask for a nationality and antiSerbianism $»^{36}$.

The culture of pleasure associated with this variety of modernity was also associated in the minds of regime ideologists with the rock 'n roll audience, and they regarded it, 
probably correctly, as interfering with nationalist mobilization for war. Ex-humanist Mihailo Marković, in his role as vice-president and chief ideologist of SPS, made his complaint against the popular culture of urban youth in martial terms : " our youth was not psychologically prepared for war. Young people lived comfortably, dreaming of a future like in "Dynasty", and now they are shocked by the fact that they have no choice but to put on a uniform, take up weapons, and go to fight $\aleph^{37}$.

Whether it was carried out consciously or not, the destruction of the rock' $\mathrm{n}$ roll market met two goals of the regime in the period of nationalist mobilization : it helped to demoralize and isolate members of the young generations of urbanites who were more inclined than any other group to resist the regime's rhetoric and plans, and it weakened a popular channel of cultural expression which was largely inclined and willing to stand in the way.

It also, however, left a void in the music scene, a diversion the regime felt it could not do without. To fill the void, state media began to intensify their promotion of neo-folk first by promoting established mainstream celebrities, and then, briefly, by widely distributing the work of nationalist - oriented performers which celebrated the ambitions of the regime and attacked its opponents. With the period of nationalist mobilization coming to a halt, publicity turned heavily to a synthesized dance-folk melange which came to be called "turbo-folk". During the time of my observation in Belgrade, two television stations were dedicated to full-time promotion of neo- and turbo-folk videos, while domestic rock 'n roll performers could be seen on a few weekend programs, some of them short-lived.

With the collapse of the interurban rock ' $n$ roll market, the confidence of Belgrade rokeri withered quickly. A sizable urban audience continued to buy such records as were produced, though these became progressively fewer, and continued to fill to capacity and beyond the few rock ' $n$ roll clubs that continued to operate in Belgrade. However, Serbia, with a population roughly equal in size to the population of the city of New York, could not support commercially a cultural market which was mostly confined to an urban minority. As the mainstream center of the rock 'n roll market shrank, the culture came to be dominated by avantgardist and purist musicians. Radovan Kupres tides the final instrument of a newspaper series on contemporary Serbian rock ' $\mathrm{n}$ roll, "Harmless, depressive, minority-oriented" 38 .

A paradoxical increase in importance - at least for members of its relatively small audience - accompanied the decline in public presence of rock ' $n$ roll. While research by Thomas Cushman ${ }^{39}$ and Anna Szemere ${ }^{40}$ chronicles crises of identity experienced by Russian and Hungarian rockers, respectively, as they emerged from undergrounds where their cultural importance was secure to commercial markets where their position was precarious (and where their former "oppositional" roles seemed suddenly anachronistic), the order of events seems to have gone in the reverse direction in Belgrade. Rock ' $n$ roll's possession of popular cultural space in the days when Yugoslavia was the most liberal, open and prosperous of East European states seemed trivial in retrospect; now their fight for a voice in the culture of Europe's poorest and most isolated dictatorship seemed a more important matter.

Where the rock ' $n$ roll culture of the relatively open "late Communist" period of the 1980s had been a successful cultural and commercial operation, the marginal rock' $n$ roll of the 1990s earned less, reached a smaller audience, and stood for more. In particular, by standing as the strongest representation of urban and international 
culture against the nationalist domination of the "peasant urbanites" and rural bosses, Belgrade rokeri during the war period acted as an antidote to the isolation imposed on young people in Serbia both from without and from within. In their stand against neofolk kitsch, rokeri also constantly reminded the urban population that war and nationalism are associated with the new dominance of semirural culture - its nativism, lack of interest in global culture, and xenophobia were epitomized by the explosion of neo-folk, and directly associated, in the minds of Belgrade rokeri, with the regime and with the war it brought on.

Rokeri saw the decline of rock ' $n$ roll in Serbia as emblematic of the defeat of urban culture generally, and the primitivci who came to prominence were directly associated in their minds with the war and the cultural decline and new criminality which came with it. When three popular Belgrade rock ' $n$ ' roll bands, Ekaterina velika, Partibrejkers, and Električni orgazam, came together as the group Rimtutituki ${ }^{41}$ to record the antiwar song «Slušaj vamo (Mir, brate, mir)» (Listen here [peace, brother, peace]), they made the association directly :

Nećemo da pobedi / We don't want

Narodna muzika / Folk music to win

Više volim tebe mladu / I love the young you more

Nego pušku da mi dadu / Than that they give me a rifle

Vocalist Zoran Kostić-Cane, who together with guitarist Nebojša Antonijević-Anton leads the Belgrade garage-rock group Partibrejkers, puts the association of elements of neo-folk culture with war clearly: "three key components of this war are : alcohol, greasy food, and folk music. Those are three points (tacke), three basic ingredients, which lead to somebody falling under the table and shouting from under there: "I'll fuck you up, you'll see $»^{42}$.

Both in their antiwar political engagement and their defense of urban culture, Belgrade rokeri combined the (innate?) rebelliousness of rock ' $n$ ' roll with a high-culture opposition to neo-folk vulgarity, associating the architects of war with the culture of their political supporters.

51 Visibly staking out a cultural position which carries clear political implications - for urban culture, for the decadence of the West, against folk nostalgia and nationalism Belgrade rock ' $n$ roll narrowed its own cultural space. As the scene took its cultural importance and cultural mission seriously, the borders of the rock 'n roll genre hardened. With production and distribution of recordings nearly impossible and press runs down to a minimum ${ }^{43}$, media access also minimal ${ }^{44}$, and with only a few performance venues, most of them small ${ }^{45}$, dedicated to rock ' $n$ ' roll musk, commercial success was out of the question. In this situation, the practice of rock ' $n$ ' roll became more difficult, more rare, and more valued.

52 War, isolation, and destruction of communication between cities meant the disappearance of rock 'n roll's commercial center. As it retreated into a harder, more hermetic form - difficult music for a minority audience - the possibility of recapturing this commercial center also retreated. Instead it became the cultural outlet of an urban minority whose cultural dominance died,to paraphrase Belgrade roker Rambo Amadeus, when Slobodan Milošević appeared. 


\section{Self-perception in the cities : popular resistance to Neo-folk} situation which Belgrade rokeri resented viscerally. The structure of control of urban cultural space had shifted dramatically in a short period of time, and neo-folk and turbo-folk were the most visible, audible and recognizable symbols of this transformation. Many members of the rock 'n roll public regarded the Belgrade scene as dead, with one denizen of KST telling me: «there aren't any places to go now for people like us. You should have been in this city ten years ago. It was really something then, the whole nightlife, young people. Now the scene is basically dead. There's just KST for me ». and viewed the decline of the city through the lens of the neo-folk ascendancy, which was associated in their thinking with the war, isolation, criminality, nationalism, and the regime.

The term novokomponovana, originally used to refer to "newly composed" folk music, took on new derisive uses in this new environment. A tasteless and garish piece of clothing would be called novokomponovano. The rare examples of new construction in Belgrade, like the high-end retail mall on Cumićevo Sokače or the massive heavy-onthe-reflective-glass showcase of the Ktitor furniture company,would be called novokomponovana arhitektura. A variety of social actors had the adjective attached to them as well. The pyramid-scheme "bankers" Jezdimir Vasiljević-Gazda Jezda and Dafina Milanovič became the novokomponovana elita. Rural political bosses and ostentatiously uneducated provincial parliamentary deputies became novokomponovani političari. This linguistic association between the servants of the regime and the carriers of regime-sponsored culture had an illustration in the wedding of turbo-folk queen Svetlana Veličković-Ceca and organized-crime king Željko Ražnatović-Arkan, the faces on either side of the equation.

With the association between the sounds of "turbo-folk" and the real conditions of life in mind, Belgrade rokeri responded to its dominance on a deep emotional level - they hated the music. One young Belgrade man, explaining that he and his friends listen only to rock 'n roll and never to turbo-folk, told me that « it hurts my soul to hear that kind of music ». In the course of a discussion on how we might respond as parents if our daughter were to date a turbo-folk enthusiast, a young father told me that his feelings ran strongly against turbo-folk because it is « the symbol of all the evil in this society ». The mother of a 12-year old girl expressed similar concern from a high-culture perspective : «my daughter constantly watches the videos on Palma, just to see what the singers are wearing. I am trying to play some good rock music for her, just so she won't think that is all there is. All these stupid songs! She has to find out that there is more to sing about than just tragic love !»

The highly publicized neo-folk was generally regarded as kitsch and "garbage" (šund), and openly contrasted, as in the young mother's comment, with rock 'n roll and other international forms which were regarded as higher and more artistically accomplished culture. At the same time rock ' $n$ roll was regarded as emblematic of both the cosmopolitanism and personal autonomy which a generation that lived in and enjoyed pre-Milošević Belgrade saw as eroding. People I spoke with voiced concern for the current generation of adolescents at whom the promotion of neo-folk is directed, 
expressing the view that a generation growing up without rock ' $n$ roll grows up without the kind of breadth and cultural support which is seen as vital if they are to "think for themselves".

Of course, Belgrade rokeri saw the neo-folk ascendancy not only as symbolizing a new equation of power and as narrowing the horizons of a younger generation. They saw it as affecting them directly, restricting the cultural space they had available and making their city less familiar and accessible to them. The same KST denizen who told me that I should have come to Belgrade ten years earlier stayed in the club after the band had finished playing, around 3:00 in the morning. When I asked him whether he would be able to catch a bus to take him home, he answered : «I just want to stay a little longer, to take in the rokerski atmosphere here. This is the only place in the city that realty suits me ».

Another Belgrader, an artist long active in the rock ' $\mathrm{n}$ roll culture, described his feelings about the loss of cultural space : « now the culture is gone, there is nothing but this garbage (šund).But our generation, we listened to rock 'n roll. That was the normal music then, it was what you heard in the kafane, over the radio. It was our music - not because it was American music but because it was international music ».

With the rise of nationalism and the ascendancy of neo-folk, the normal delineation of the "normal" shifted dramatically. While participating in and enjoying international consumer culture had been normal for a generation, suddenly it was not. The new normalcy of narrow national identity, local kitsch, and closed access to the world was felt as constraining. More than this, it was one constant reminder of the changed terms of life in the war regime.

61 The connection between the neo-folk ascendancy and the character of the regime was made frequently in my conversations with Belgrade rokeri. Sometimes coincidence was taken to be sufficient to draw the association - most people observed that neo-folk had not been so predominant before the war period, and most observed that state controlled media were most involved in promoting the genre ${ }^{46}$. In some cases the association was made generally, as by the high-school student who told me " we get the culture we deserve ». Some of the people with whom I spoke were more precise in discussing the role of state-provided publicity for the promotion of neo-folk: « look at the ads on RTS. If the publishers had to pay for all the advertising time their albums get, they would have to sell hundreds of thousands of albums. But they don't . It's the same company [RTS, which includes both the state television network and the music publishing company PGP-RTS] promoting its own products ».

Others looked for connections in the amorous lives of performers, real or imagined. At the same time, some did their best to deny that the music was as popular as it seemed to be - a potentially credible claim, considering that I encountered very few people who claimed to like neo-folk and a considerable number who despised it ${ }^{47}$.

63 For all of these respondents, the impressive public presence of neo-folk and its turbofolk derivative could be traced directly to institutions controlled by the regime, the cultural and political orientation of the regime, and the demographic base of regime support. Rather than an "organic" manifestation of public taste, the neo-folk ascendancy was viewed as an imposition from above - as was the increasingly limited cultural space accorded the rock 'n roll culture. 

acquired the power of counter-identity in two respects. On the one hand, in contrast to its ascribed cultural value in most parts of Western Europe and America, rock ' $n$ roll is perceived by Belgraders as high art, and implicitly opposed to neo-folk which is regarded as "Balkan" and "primitive". In the nationalist-authoritarian environment of Belgrade, the epithet of "primitivism" applied also to nationalist ideology and to the party in power ${ }^{48}$.On the other hand, its increasingly limited audience and more limited range of venues qualified it as a minority urban cultural formation in opposition to the semirural and omnipresent variations of neo-folk. In this regard rokeri came more and more to see themselves as the last line of defense of urban culture. At the presentation of Milan Mladenović's posthumous album, one presenter hailed "the Belgrade that defends itself against the savages who attack it". More picturesquely, the presentation took place underground, albeit in a lavishly restored catacomb in Belgrade's Kalemegdan fortress. The image is nonetheless apt : nearly all of Belgrade's rock ' $n$ roll venues are housed in basements, adding a geographic and spatial dimension to the image rokeri have of themselves as constituting an underground culture. difference from all that was mainstream, popular, and promoted in state media. One fan praised an album by the band Instant karma in boundary-defining terms : " this is pure (cist) rock ' $n$ ' roll, it doesn't have any folk in it». The ideology of rock ' $n$ ' roll authenticity made for some shifts in the "Yugo-rock" canon, so that the once-adored Bijelo Dugme, who had been producing rock covers of folk tunes since the mid-seventies, came to be regarded less as domestic pioneers of cultural fusion and more as the precursors of turbo-folk ${ }^{49}$. Similarly, rokeri who abandoned the rebellious postures of rock ' $n$ ' roll, like Bajaga and Bora Đorđević, came to be increasingly regarded as outside of the rock ' $n$ ' roll culture. Conversely, this meant that otherwise mainstream figures who maintained a strong anti-regime and antiwar posture approached the status of underground heroes.

In a similar way, small successes in the field of rock ' $n$ roll came to be perceived as victories in the ongoing cultural conflict. The winter of 1994 was a dark period for Belgrade rock 'n' roll - Milan Mladenović had just died, the Partibrejkersi were inactive, few new appearances were being made - and a dark period literally in Belgrade. During the month of December, according to the report of the Serbian electrical utility, districts of the city were subject to scheduled "reductions" in electricity lasting from two to four hours on 28 of 31 days of the month ${ }^{50}$.As it turned out, one of these "reductions" began as the band Darkwood dub was preparing to hold a long-awaited concert in KST. As a large crowd, larger than the capacity of the club ${ }^{51}$, gathered and waited outside, a fan approached me proudly : « do you see all these people? And this concert had no advertising at all, no posters, no radio announcements. But all these people found out and came ».

After midnight had passed, electricity came and the concert was able to begin, and the hard noise of the band offered an appropriately angry and loud counterpoint to the darkness and silence of the long wait which preceded the show. Reviewing the performance in Borba, Nenad Jevtić brought together the band's bad-luck history, the cultural climate of the city, and the uncertain supply of electricity into a description of a night against fate :

Balkanologie, Vol. IV, $n^{\circ} 1$ | 2000 
Many things have conspired against Darkwood dub. Still more against the young people of this city who live on the edge of honor, devalued and abandoned to themselves. Maybe it has always been that way, maybe not. Once in a while that darkness releases from its bosom events like Darkwood dub which redefine things and to some degree classify them. We are here and now, things do not come easily for us, but that is the way it is. Belgrade is a dark forest with no end. You are in it. Pay attention to yourself and to those near you because all kinds of things happen in the dark (Darkwood dub, for example) ${ }^{52}$. was difficult to maintain in an environment in which the local and the national had become the defining principles, and isolation from other cultures nearly compulsory. Isolation played a psychological role as well, leading some rokeri to wonder whether they were falling behind events in the commercial and cultural centers of other countries, and encouraging a tendency among local urbanites to think of themselves as backward Balkan versions of metropolitan models. A critic insults a Belgrade hardcore band in terms that suggest that that musical genre has no place in a peripheral country: « ha, ha, ha, a HC band that buys sausages at the farmers' market and gets salmonella poisoning. Now please, there is none of that in hardcore $»^{54}$.

In this case, the nostalgia for international cultural forms carries with it a rejection of the domestic, and of lived experience, as somehow not measuring up to the cosmopolitan standard. This rejection encompasses not only such particular forms as turbo-folk, but also such ordinary aspects of everyday experience as sausages, shared 
(with varying degrees of enthusiasm, no doubt) by members of widely differing taste cultures.

In order to maintain their attachment to the international culture they like, many local rokeri find it necessary to reject various aspects of their own lived experience. The decision carries with it some tension, indicated, for example, by a subculture magazine's description of the turbo-folk club Folkoteka in their guide to the city's clubs : « is Folkoteka a place to avoid? Of course, but then when you consider the question maybe it would not be so bad if you were to drop .by once, to see what kind of country you are living in $»^{55}$.

75 Clearly many did not decide to educate themselves in that way, but rather to choose some other experiences, whether they are theirs or not, from other places. One young Belgrader explained to me how the signal of MTV, pirated after hours on several local television stations, helped him to cope psychologically. Another explained to me how she maintains her sanity by "living like I'm on another planet ", studiously avoiding local cultural products and especially news, determined to follow only foreign music and films. And of course, a frequent topic of conversation among young Belgraders is the question of whether to move to another country.

\section{Dancing in and out of the public sphere}

76 In articulating their fascination, rejection and disgust about genres of popular music, Belgraders engaged in a discussion which was not permitted on the formal level : about the transformation of the population and character of cities under the nationalistauthoritarian regime, about the rise of a new criminal elite, and about the disappearance of cultural, economic and political opportunity for the younger generation. This migration of the public sphere into the area of private pleasure and taste did not occur incidentally or without notice. The self-identified members of Belgrade's rokerski public with whom I spoke saw the regime as being in cultural opposition to them, and saw neo-folk and turbo-folk as the instruments of that opposition, experienced every day in the diminution of cultural space and its takeover by neo-folk culture. As neo-folk and turbo-folk came to be reflexively associated with dictatorship, "primitivism", criminality and war, disgust with those cultural forms took on the quality of a badge of opposition to its perceived correlates. In the cultural environment of 1990s Serbia, the statement that a person hates «turbo-folk and everything it stands for » leaves no questions unanswered, either with regard to the identity of turbo-folk or to the specificity of what it stands for.

77 At the same time, the "debates" around music and popular culture were the only form available in which issues dictatorship, "primitivism", criminality and war could be openly addressed, under cover of being a discussion about cultural messages and markets, or about cultural values and "kitsch". More than this, these questions could be engaged with at a level of emotion (and detail) more characteristic of punk rock than of parliamentary deliberation suggesting that the possibility existed, if not to materially affect the position of the new criminal elite, to at least make clear what detractors of their culture thought of them.

78 As powerful as the negative cultural expression of the Belgrade rokeri may have been on the level of self-perception and identity, it is a foregone conclusion that the effect of this cultural expression on political life was negligible. Music offers at best a weak 
means to intervene materially in the public sphere, and their music represented the tastes and orientations of an urban minority which was shrinking both in size and influence. If the question were asked directly: how much power is the power of signification, the answer would have to recognize that while there may be considerable power on the level of the individual, cultural power can not very often substitute for or directly confront real power.

In this case, however, the point is not to change the situation but to interpret it. One of the crucial questions in approaching East European societies at the time is who supports nationalist regimes and projects, under what conditions and why. Conventional political research can offer trace evidence on the question - we do know statistically, for example, that pro-regime parties have their strongest bases of support in more rural and less "mixed" areas, while maintaining a bad and worsening position in cities. We also know that at the time of the student and citizen protests of 1996-1991, every major population center in Serbia was the site of an opposition election victory and of daily demonstrations. Conventional political research cannot tell us, however, what issues and conflicts divide the generally pro-regime from the generally anti-regime population, or how the differences and divisions among them are experienced and articulated in everyday life. The types of sources generally used in researching issues in the public sphere do not address these conflicts openly, as they are generally exiled from political and public discussion. while they may be the object of manipulation, they are rarely if ever the object of deliberation.

In order to approach the question, then, it is necessary to go outside of the formally "public" sphere and over to the place, as Goffman puts it, "where the action is " ${ }^{56}$. Not everything which is considered in political bodies is experienced in everyday life, nor certainly is everything experienced in everyday life considered in politics. But everything which matters in everyday life is elaborated and articulated somewhere.

\section{NOTES}

1. Williams (Raymond), "Moving from High Culture to Ordinary Culture ", in McKenzie (Norman), ed., Convictions, London : MacGibbon \& Kee, 1958, p. 6.

2. Simić (Andrei), The Peasant Urbanites: A Study of Rural-urban Mobility in Serbia, New York: Seminar Press, 1973.

3. Gordy (Eric D.), The Culture of Power in Serbia: Nationalism and the Destruction of Alternatives, University Park : Pennsylvania State University Press, 1999.

4. Vujačić (Veljko), Communism and Nationalism in Russia and Serbia, unpublished PhD dissertation, Berkeley : University of California, Department of Sociology, 1995.

5. Gordy (Eric D.), op. cit.

6. Vujović (Sreten), «Stereotipi o gradu, nacionalizam i rat », Republika, (113), 1-15/04/95.

7. Inkeles (Alex), Smith (David H.), Becoming Modern : Individual Change in Six Developing Countries, Cambridge: Harvard University Press, 1974 ; Fischer (Claude S.), The Urban Experience, New York: Harcourt Brace Jovanovich, 1976 ; Fischer (Claude S.), To Dwell Among Friends: Personal Networks in Town and City, Chicago : University og Chicago Press, 1982. 
8. Mayer (Arno), Why Did the Heaven not Darken? The "Final Solution" in History, New York: Pantheon, 1988.

9. Ivan Čolović (Divlja književnost, Beograd : Nolit, 1985, pp. 142-143) dates the beginning of the "new folk songs" movement to 1962, contemporaneous with the expansion of local radio stations in Yugoslavia. However, he points out that more "traditional" folk songs are often also relatively recently authored compositions in the folk style : «Few people know that the well-known songs "Jesen prole, ja se ne oženih" (Spring Is Passed, and I Have Not Married), "Jesi l' čuo mili rode" (Have You Heard, Dear Relative), or "Lepo ti je biti čobanica" (It Is Nice for You to be a Shepherdess), which seem to come from ancient pastoral days were written around 1950 by Dragiša Nedović of Kragujevac, and the music composed by Miodrag Krnjevac » (ibid., p. 141).

10. Ibid., p. 49.

11. There were, of course, neo-folk listeners in cities as well. A hint as to the origins of a part of this audience can be found in the idyllic-rustic themes of many neo-folk songs, as well as in specific nostalgic themes (i.e., "U gradu sam sada, al' se slu divim" [I am in the city now, but I envy the village]). An anticosmopolitan orientation can be found to complement the anti-urban inclination, as in Miroslav Ilić's lyric: "Ameriko, zemlja velika / Ali metar moga sela, Amerika cela » (America, a big country / but one meter of my village is all of America). A part of this anticosmopolitanism can perhaps be attributed to the fact that for many Yugoslavians, especially from rural areas, the only contact they were likely to have with other countries was the unpleasant experience of being a "guest worker".

12. It should be pointed out that the emphasis here is on neo-folk, and not on the assortment of traditional styles usually called "izvorni", or "authentic" folk. The cultural conflict between the "izvornis" and the "neos" within folk reaches, in many cases, the same pitch as did the cultural conflict between "rokeri" and "narodnjaci" in the war years. See Čolović (Ivan), op. cit., p. 148), or for that matter the letters column of any of Serbia's folk-fan magazines such as Sabor or Huper. "Authentic" folk, however, is a minority music on a level with symphonic music, its performance most often restricted to professional ensembles of trained musicians, while "neo-folk", like most other commercial forms, is a performed principally by self-educated performers. Andrei Simić describes the distinction as follows : "detractors [of neo-folk] employ a variety of derogatory expressions such as "clippity-clop national music" and the like. In this negative framework the implied comparison is with so-called "authentic national music" (izvorna narodna muzika) an expression limited to an increasingly rare, orally-transmitted village tradition, and to performances by professional and amateur folklore groups often composed of educated elites who in other contexts reject popular folk culture, especially when it is associated with their contemporary social inferiors" (Simić (Andrei), "Commercial Folk Music in Yugoslavia: Idealization and Reality ", Journal of the Association of Graduate Dance Ethnologists, 2, fall-winter 1978, p. 27). Simić goes on to claim of "authentic national songs " that "perhaps their major audience consists of foreign folk-song and dance enthusiasts ».

13. Čolović (Ivan), op. cit., p. 158.

14. The emphasis here is on artists willingly offering their services for nationalist publicity. Ivan Čolović cites two cases in which a rock ' $n$ roll band, Električni orgazam, was involuntarily used for a similar purpose, in the chants of football fans which often took a nationalist character. The chorus of one of their songs :

Igra rokenrol cela Jugoslavija Dance to rock'n' roll, all of Yugoslavia

Sve se ispred tebe ispravlja i savija Everything before you folds and unfolds

was rendered by patriotic football. fans to include the lines (in the version of fans of Belgrade's team Partizan) :

Samo pravi Srbin za Partizan navija Only real Serbs root for Partizan

And, alternately (in the version of fans of Split's team Hajduk) :

Samo pravi Dalmatinac za Hajduk navija Only real Dalmatians root for Hajduk. 
See Čolović (Ivan), « Fudbal, huligani i rat », Republika, (117), 1-15/06/95.

15. Čolović (Ivan), Bordel ratnika., Beograd : XX vek, 1994, p. 23.

16. Ibid., p. 103.

Any association between the title of this song and the King Crimson classic «Twenty First Century Schizoid Man» is probably coincidental, as the two do not resemble one another musically. The King Crimson song was covered by the Rijeka band Let 3 on their 1994 album, Peace. Several examples of the music with which Radovan Karadžić promoted himself and his para-state can be observed in the film Serbian Epics (London: BBC, 1993). Consistent with his representation of himself as an heir to $19^{\text {th }}$-century folklorist and language reformer Vuk Stefanović (Radovan's evidence that they are related : they both appear to have dimples on their chins), Radovan claimed to prefer epic poetry to the more commercial variants of neo-folk.

17. To these aesthetic qualifiers one might also add that the lyrical content of the songs seems to fall into three general categories : 1) insults directed toward political leaders on the opposing sides, 2) threats, often of sexualized violence, toward the same, and 3) claims about the historical ownership of particular areas of land. See the selection of songs offered by Luković (Petar), « Šta pevaju Srbi i Hrvati ", Vreme, (110), 30/11/92, pp. 29-32.

18. For several examples, see Dragičević-Šešić (Milena), Neofolk kultura: publika i njene zvezde, Novi Sad: Biblioteka elementi, 1994. There were distinctions between Serbia and Croatia, however. Reflective of the fact that neo-folk had always been more popular in the "eastern" republics (Serbia, Montenegro, Bosnia-Hercegovina, Macedonia) than in the "western" ones (Croatia. Slovenia), nationalist agitprop in Croatia inclined toward the pop end of the scale as much as to the folk end. Hence saccharine nationalist compositions like Danke Deutschland (see Janjatovic (Petar), "Yugoslav Civil War Halts Growth of Local Music Biz ", Billboard, 104 (28), 11/07/92) and the songs by Tomislav Ivčić encouraging Croatian expatriates to "come home".

19. Bogdanovic (Srboljub), « Phillips Višnjić », NIN, November 1993.

20. Ilić (Dragan), « Keba i Stonsi », Imperium of Trivia (Belgrade’s fanzine), 1994.

21. Simić (Andrei), art. cit.

22. Ibid.; Dragičević-Šešić (Milena), op. cit.

23. I am indebted to Dragan Ilić for making this evolution of form clear to me in his descriptions of the history of neo-folk style and the neo-folk constellation of references.

24. Simić (Andrei), art. cit. ; Čolović (Ivan), Bordel ratnika (op. cit.).

25. Drawing further on the analogy presented by Simić and Dragišević-Šešić between neo-folk and American "country-and-western", the increasingly technologized and commercialized mainstream country coming out of present-day Nashville has led one old-time country singer (a parallel to the "authentic" folk musicians of Serbia ?) to respond to a recording, "I don't know what country that music is from ». Tagg (Philip), unpublished address at the conference of the International Association for the Study of Popular Music, Glasgow, 1995.

26. G. (Lj.), « Novokomponovani rok », NIN, 09/12/1994, p. 35.

27. Interestingly, if cosmopolitans objected to appropriation of another type of international culture by turbaši - the kind represented by "Coca-Cola, Marlboro, Suzuki" - it was not on the same ground. The consumption of imported luxury objects is more generally associated with the conformist "šminkeri", and carries with it a connotation of inauthenticity. Hence it could be argued that both rokeri and narodnjaci cultivated some kind of relationship with the (outside) consumer world, but that a significant distinction was made between relations bounded by culture and those defined by other than cultural consumption. For a discussion of the style of "šminkeri" and various responses to them, see Prica (Ines), Omladinska potkultura u Beogradu: Simboli ka praksa, Beograd: SANU etnografski institut, 1991 and Joksimović (Snežana), Marić (Ratka), Milić (Anđelka), Popadić (Dragan), Vasović (Mirjana), Mladi i neformalne grupe: u traganju za alternativom, Beograd : Istraživačko-izdavački centar SSO Serbije / Centar za idejni rad SSO Beograda, 1998. 
28. In Kupres (Radovan), «Srpski režim i srpski rok: od presije do kolaboracije » (three part series), Naša Borba (internet izdanje), may 1996.

29. Radio Student, «Enlistment to Radio Student's Boradcasts : The Present Weekly Program Scheme », Ljubljana, 1995.

30. The well-off and well dressed young crowd which congregated in these and similar venues were known at the time as šminkeri (makeup wearers), their values opposed to those of the pankeri (punks) and hipici (hippies). For a detailed analysis of these groups and their various styles of self-presentation, see Prica (Ines), op. cit. By the time I had arrived in Belgrade, the heirs to the šminkeri had become the fancies, the various elements of rock ' $n$ roll culture were mostly grouped under the general category of padevičari (epileptics), and of course the neo-folk youth were added to the mix either as narodnjaci (folkies, or, in M. Živković's felicitous translation, "folknjaks" [Živković (Marko), «Stories Serbs Tell Themselves (and Others) About Themselves : Discourses on Identity and Destiny in Serbia Since the Mid-eighties ", unpublished dissertation prospectus, University of Chicago, 1996]) or dizelaši (diesels).

31. Indeed, probably the finest live album in "Yugo-rock » is Električni orgazarn's Braćo $i$ sestre (Brothers and sisters) (1987), recorded in Zagreb's Kulušić auditorium. And certainly Gile's most poignant song is his remembrance "Zagreb", from his 1988 solo album Evo sada vidišda može (Now you see it can be done).

32. Bora Đorđević achieved tremendous popularity with the band Riblja Čorba (literally, Fish Chowder, though the name also contains an implicit obscene connotation) in the first several years of the band's existence, mostly through his comic songs which were principally about his own drunkenness and oafishness. At the same time, several of Riblja Čorba's early songs became anthems of anti-Communist rebelliousness, especially «Pogledaj dom svoj, Anđele» (Look Homeward, Angel), « Na zapadu ništa novo » (Nothing New in the West [also the Serbo-Croatian title of Remarque's All Quiet on the Western Front]), and « Neću da budem član Mafije » (I Don' Want to Be a Member of the Mafia). When his writing turned to politics, Đorđević combined his antiCommunism with hard Serbian nationalism, especially in his published collections of verse, particularly Neću (Beograd : self-published, 1989) and Hej Sloveni! (Beograd : Glas, 1987). During. the same period, the Union of Serbian Writers (Udruženje književnika Srbije - UKS)was crystallizing its nationalist positions, and elected Đorđević a member, trying in Leninist fashion to legitimate itself by bringing on a "leader of youth". Losing the comic irony which had once characterized his songs, Đorđević took easily to the flattery, began signing his texts as "the writer (književnik) Bora Đorđević"and gave himself over to political agitation in the nationalist cause. Where the rock critic Petar Luković had once referred to him as "the first Serbian rock star" (Luković (Petar), Bolja prošlost. Prilozi iz muzičkog života Jugoslavije, 1940-1989, Beograd: Mladost, 1989), the weekly rubric which Luković directs of amusing and appalling quotations in the newsweekly Vreme would henceforth refer to him as "professional Serb".

33. The term "turbofolk" was coined by rocker Rambo Amadeus to describe his satiric cooptation of neo-folk forms and imagery. However, commercial neo-folk performers who lacked Rambo's irony adopted the term for themselves, and it came to refer less critically to an amplified and synthesized dance kitsch form, which received tremendous commercial promotion.

34. According to Mirjana Prošić-Dvornić, «there are various estimates of the success, or lack of success, of [military] mobilization, but all of them fall below $50 \%$. For Belgrade, where, along with multiethnic Vojvodina, resistance was strongest, it is estimated that as many as $80 \%$ of reservists did not appear for mobilization ». Prošić-Dvornić (Mirjana), ed., Kulture u tranziciji, Beograd : Plato, 1994, p. 196 fn. 17).

35. Ćosić is generally assumed to have been the principal author of the 1986 "Memorandum" of SANU laying out the grievances of Serbia against other republics and the Albanian minority in Yugoslavia. He lent legitimacy to Milošević during the period of his ascent to power by offering 
"neutral support" to the new dictator, and continued to lend it by becoming the first president of the Federal Republic of Yugoslavia (Savezna Republika Jugoslavije - SRJ) which was constituted by Serbia and Montenegro.

36. Vujačić (Veljko), op.cit., p. 249.

37. In Prošić-Dvornić (Mirjana), op.cit., p. 191.

38. Kupres (Radovan), art.cit.

39. Cushman (Thomas), Notes from Underground: Rock Music Counterculture in Russia, Albany: SUNY Press, 1995.

40. Szemere (Anna), «Subcultural Politics and Social Change: Alternative Rock Music in Postcommunist Hungary ", unpublished paper presented at the conference of the International Association for the Study of Popular Music, Nashville, 1995.

41. The name of the ad-hoc band is a complicated play on words with an obscene connotation. The band was joined in performances in Belgrade by Rambo Amadeus, and again at an antiwar concert in Prague by the Zagreb band Vještice (Witches). Sarčević (Jasna), «Muzika za nostalgičare ", Borba, 24/10/94, p. 15.

42. Stakić (Vladimir), « Monoview : Zoran Kostić-Cane, Paetibrejkers », Vreme zabave, May 1994.

43. In early 1995 Elekrični orgazam,one of Yugoslavia's most popular rock ' $n$ ' roll bands, released an ambitious double album, Zašto da ne ? (Why not ?), which marked its return to recording after a three-year hiatus as well as the band's $15^{\text {th }}$ anniversary. The album was initially released with a press run of 500 copies.

44. To take television appearances as a key example, while two stations (TV Pink and TV Palma) were oriented exclusively to promotion of neo-folk videos, and while neo-folk records received heavy promotion on the three state-owned television stations, programs showcasing domestic rock 'n roil were sparse. The "semi-independent" TV Politika had one Sunday program, "Paket aranžman", the third channel of the state television included a "domestic top ten" on its Sundayafternoon top ten countdown but cancelled its regular domestic rock 'n roll program "Klati se i valjaj" (a rather literal translation of "rock and roll"), and the independent Studio B (taken over by the government in 1996) had intermittent programming.

45. The largest rock ' $n$ roll venue was Prostor, in the premises of a former movie theatre. Remaining clubs were generally basement rooms, like Akademija until it was closed in winter of 1995. The city's principal rock 'n roll venue, the Technical Students' Club (Club studenata tehnike KST) could hold around 500 people in its "summer garden". Otherwise its main room could hold a bit more than 200 people, if they held their arms closely at their sides.

46. In addition to heavy advertising and program promotion on the state RTS network, the statecontrolled newspaper Večernje novosti promoted neo-folk celebrities both in its paper as well as on the radio station it owned, Radio Novosti. The two neo-folk television stations in Belgrade, both of them set into motion without the inconvenience of applying for a frequency, had their offices in the headquarters of Milošević's SPS (TV Palma) and Mirjana Marković's SK-PJ (TV Pink).

47. These self-reports, however, should not be taken at face value. Many of the people who claimed to never listen to turbo-folk, when I prompted them with the firstlines of a verse, would happily complete the verse for me. At the same tune, nearly everybody with whom I spoke, whether lovers or haters of turbo-folk or not strongly inclined either way, knew the products of the genre well enough to joke extensively about songs, celebrities, and video images.

48. Hence the references enumerated by M. Živkovićassociating the Miloševi \} regime with the Ottoman Empire (Živković (Marko), «The Turkish Taint : Dealing With the Ottoman Legacy in Serbia ", unpublished paper presented at the conference of the American Anthropology Association, Washington, 1995). Hence also the introductory line of Rambo Amadeus's anti-regime song «Prijatelju, prijatelju »(My friend, my friend), which precedes a string of obscenities with « Kada primitivci dođu na vlast» (When primitives come to power). In concert, Rambo dedicates the 
song to « doktor Buldog Sloba » and « doktor Pingvin Franjo », that is to presidents Milošević and Tuđman.

49. People do not abandon things they love, or once loved, so easily, however. At one party in Belgrade, when the host put on a Bijelo Dugme record, the assembled guests, all convinced rokeri improvised rough approximation of a kolo dance in the host's small room.

50. Perović (M.), «Za otklanjanje kvarova do tri godine », Politika, 27/03/95, p. 17. Scheduled "reductions" account for only a part of the darkness of that winter. Several "reductions" occurred either unscheduled or lasted considerably longer than scheduled. Some of the "unscheduled" reductions were in fact the result of technical failures and their duration was of unpredictable length.

51. Borba'sreviewer estimated the crowd as being "something less than 900 people ». Jevtić (Nenad), « Posle mraka - Mrak! », Borba, 21/12/94, p. 16.

52. Ibid.

53. For example, the evening was probably less than sublime for one friend whose nose was broken by an overly spirited dancer at the concert.

54. Džogović (Vesna), « Vodić kroz trendove : we're sick of it all », Talas, April 1995, p. 41.

55. (unsigned), « Tema broja : noć u Beogradu », Talas, April 1995, p. 28.

56. Goffman (Erving), Interaction Ritual : Essays on Face-to-Face Behaviour, New York : Doubleday, 1967.

\section{AUTEUR}

ERIC D. GORDY

Department of Sociology, Clark University. 